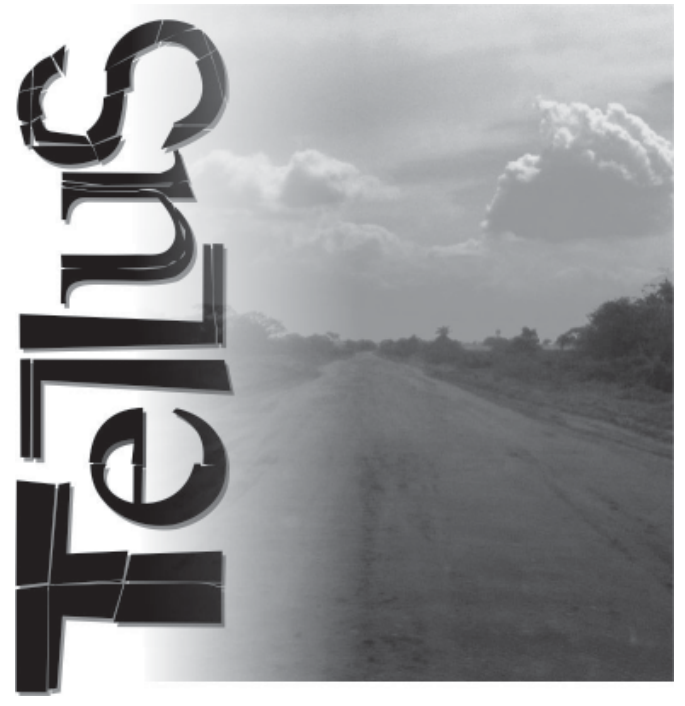

documentos 



\section{Entrevista com Antonio Jacó Brand Interview with Antonio Jacó Brand}

\begin{abstract}
Meire Adriana da Silva*
[...] na realidade de Mato Grosso do Sul é muito difícil você justificar a presença de um pesquisador na área, pesquisador tradicional, que faz sua pesquisa e depois vai embora [...] os povos indígenas cobram isso, é direito deles o retorno desse trabalho [...]
\end{abstract}

\section{Apresentação}

Esta entrevista foi realizada com o professor Antonio Brand, no dia 24 de outubro de 2004, em sua casa, no município de Campo Grande, MS. Ela é decorrente do desenvolvimento da minha pesquisa de mestrado, realizado entre os anos de 2003 e 2005, na então Universidade Federal de Mato Grosso do Sul/Campus de Dourados. A pesquisa, que resultou na dissertação O Movimento dos Guarani e Kaiowá de Reocupação e Recuperação de seus Territórios em Mato Grosso do Sul e a Participação do CIMI (Conselho Indigenista Missionário) 1978-2001, foi orientada pelo professor Cláudio Alves de Vasconcelos e contou com a participação do professor e amigo Antonio Brand. Essa participação ocorreu a partir de 2000, por meio de minha convivência, ao mesmo tempo, com os Guarani e Kaiowá e com Brand, que contribuiu profundamente na minha vida pessoal e profissional. Seu visível envolvimento político com os povos indígenas e em especial com os Guarani e Kaiowá, fez aumentar minha admiração por um ser humano que soube, ao longo de sua carreira acadêmica, associar ciência e respeito aos povos indígenas.

A entrevista foi um dos pontos relevantes para a conclusão do meu trabalho, pois, nela, Brand demonstra a importância do apoio a esses povos e, ao mesmo tempo, destaca-os como sujeitos de sua história. Espero que sua publicação possa servir de inspiração, para que nós pesquisadores e futuros pesquisadores, indígenas e não indígenas, façamos das várias
* Professora da Universidade Federal do Amapá - Curso de Licenciatura Intercultural Indígena.

E-mail: meire@unifap.br
Tellus, ano 12, n. 23, p. 179-192, jul./dez. 2012

Campo Grande, MS 
ciências produzidas em nossos espaços de saber, uma grande contribuição para a melhoria da qualidade de vida dos povos indígenas, a exemplo desse valioso legado.

\section{Professor Antonio Brand, fale de sua atuação no CIMI junto aos Guarani e Kaiowá em relação à luta pela terra em Mato Grosso do Sul.}

BRAND: Bom, eu acho que o trabalho do CIMI em Mato Grosso do Sul [MS] não pode, de jeito nenhum, dissociar do trabalho do CIMI no Brasil e do próprio surgimento do CIMI e dos principais conflitos que o CIMI vivenciou neste primeiro período. O CIMI foi fundado em 1972. O trabalho do CIMI, ele começa com um levantamento geral no Brasil da situação das populações indígenas, um levantamento que ninguém tinha na época, saber onde é que estavam os índios, qual era a situação especialmente das terras. Esse levantamento foi conduzido entre os anos 1974 e, no bojo desse levantamento, uma equipe veio também ao MS fazer aquele relatório que você conhece, escravidão, aquele texto publicado. O CIMI na verdade se apoia nesse levantamento feito no Brasil inteiro, neste panorama da situação dos índios no Brasil. Este levantamento deu um quadro extremamente precário em termos dos povos indígenas no Brasil. Então, por isso o CIMI, quando realiza a sua primeira Assembleia Nacional de Pastoral Indigenista, em 1975, a questão de fundo é a questão das terras indígenas, como primeira grande bandeira de luta. Eu participei, vinha participando da diretoria do CIMI desde o início, nos anos de 1975, 1976 até 1978, fui coordenador do setor de formação do CIMI nacional. Como coordenador do setor de formação, eu tive, na ocasião, que organizar e participar nas diversas regiões do Brasil de pelo menos oito cursos intensivos de indigenismo, como era chamado, que eram cursos de 21 dias centrados fundamentalmente no estudo da conjuntura indígena no Brasil. Tinha uma semana de conteúdos antropológicos, tinha o estudo da legislação e também da pastoral.

Esses cursos de indigenismo que eu organizei e coordenei pelo CIMI, contavam também sempre com a participação dos maiores antropólogos da época, Darci Ribeiro, Carmem Junqueira e vários outros que eram antropólogos, Carlos Moreira Neto, enfim, eles todos participavam destes cursos. Então, a minha ida ao MS se deu após, ou no bojo, desta ampla participação, já anterior nas discussões da situação indígena, do trabalho da Igreja e do CIMI. Agora, era uma época que obviamente o conflito aberto era o confronto direto com o governo e com a FUNAI, porque a FUNAI era o órgão que em 1973, pelo Estatuto do Índio, tinha como meta demarcar as terras indígenas em cinco anos, o prazo era 1978. Tudo isso estava em vigor, estava andando. O CIMI, ao centrar seu trabalho na questão da demarcação do território, obviamente que ele confrontou diretamente com a FUNAI. E através da FUNAI, 
com o governo. Então, em 1975, junto com a primeira Assembleia Nacional do CIMI, vieram inúmeras proibições aos missionários do CIMI, em diversas regiões do Brasil, de ingresso em áreas indígenas. E, simplesmente, em várias regiões os membros, as pessoas identificadas com o CIMI, eram proibidas pela FUNAI de ingressar em áreas indígenas. No MS, no entanto, a FUNAI, o governo federal nessa sua política com a Igreja, logicamente percebia que a Igreja nunca foi algo unívoco, então o governo buscava, em algumas regiões, dividir a Igreja aproximando-se de algumas Dioceses, estimulando a elas se posicionarem contra o CIMI e, nesse sentido, fazer um trabalho conjunto com a FUNAI. O estado onde o governo mais investiu foi Mato Grosso do Sul, nesse sentido de mobilizar a Diocese daqui, que tinha uma postura política, digamos, mais fechada, e então de manter uma vinculação, uma articulação com a FUNAI. No bojo disso, organizou (eu tenho escrito sobre isso) vários seminários entre as Missões e a FUNAI, e várias vezes eles ocorrem aqui no MS. Esses seminários eram, exatamente, por parte da FUNAI, um esforço de um lado para isolar o CIMI dentro da Igreja e de combater, digamos assim, essa linha do CIMI, do setor da Igreja Católica que se posicionou claramente favorável à demarcação das terras, aproximando-se dos setores que divergiam dessa orientação.

Então, quando eu vim para o MS, esse era o quadro, aqui era o lugar forte onde a FUNAI tinha uma articulação. A cada ano, tinha reuniões entre a FUNAI e a Igreja Católica sobre a questão indígena, era de certa forma uma articulação contra o CIMI por parte da FUNAI. Bom, no entanto, esse era o quadro aqui, eram reuniões grandes das quais participavam a Diocese de Corumbá; depois dividiu Jardim. Naquele tempo era Corumbá, Dourados e Campo Grande, as três Dioceses que participavam desses encontros, de onde vinha toda a cúpula da FUNAI. No entanto, o Bispo de Dourados, Dom Teodardo, ele, ao mesmo tempo tinha uma aproximação com o CIMI, pediu já há mais tempo para a gente trabalhar na Diocese dele. O CIMI é a primeira ONG indigenista que surge no Brasil nesta questão e a Operação Anchieta [OPAN], fundada em 1969. O CIMI, ao se constituir em 1972, pega praticamente todos os quadros da OPAN e que vão constituir o Secretariado Executivo do CIMI, a começar pelo Padre Egidio, que foi o primeiro secretario.

Então a OPAN tinha um convênio de cooperação com uma organização austríaca, uma organização de voluntariado austríaco. Então no bojo deste trabalho, aqui em Dourados, o trabalho aqui com os Guarani, ele foi iniciado através do CIMI por membros da OPAN, que, no caso, era eu e um casal dessa organização austríaca, isso em 1978, e com o apoio de Dom Teodardo. Embora participasse das reuniões com a FUNAI, ele tinha uma postura crítica sobre esses encontros, isso está escrito em vários lugares, ele achava que a FUNAI de fato não estava cumprindo com as obrigações e que estava buscando manipular a Igreja.

Tellus, ano 12, n. 23, jul./dez. 2012 


\section{Você era coordenador de formação do CIMI Nacional antes de vir para Dourados?}

BRAND: Quando eu vim para Dourados, continuei como coordenador do setor de formação do CIMI Nacional, eu segui mais um ano com esse trabalho. Então, éramos oficialmente vinculados ao CIMI, mas aqui na Diocese nós estávamos a serviço da Diocese. Aí em 1978, 1979, eu creio, entra um presidente civil na FUNAI. Ademar Ribeiro, eu acho, presidente civil na FUNAI; e na conjuntura nacional, há um período de distensão nas relações entre o CIMI e o governo. Nesse bojo dessa distensão, dessa busca de cooperação entre a FUNAI nacional com o CIMI, na tentativa de aproximação é que eu participei da primeira comissão de identificação da Área Indígena Paraguassu, em 1979. Acho que foi chefiada, na época, pelo antropólogo, o Romero; ainda hoje ele está na FUNAI, Cláudio Romero.

Então, nós tínhamos um período de distensão de novo e, desde lá, a relação com a FUNAI sempre foi uma relação de mais ou menos tensão, de mais ou menos proibição, mais ou menos radical. A forma de trabalhar aqui variava conforme mudava um pouco a conjuntura nacional, aí já não era mais uma questão com os Bispos. Os Bispos, a essas alturas, depois de 1979, 1980, reconheceram que o CIMI era um organismo da CNBB; enfim, esse problema interno, ele foi mais ou menos resolvido. Então, oficialmente, passou a ter aqui a coordenação do CIMI regional, mas passou a depender muito mais do nosso maior ou menor conflito com a FUNAI, das articulações nacionais, da conjuntura nacional que sempre oscilou muito.

\section{E o fato de o CIMI ter sido anexo e não relacionado à CNBB...}

BRAND: Bom, eu acho que é importante essa questão do Bispo, da Igreja. É obvio que o CIMI aglutina um setor inicialmente muito pequeno da Igreja Católica no Brasil, que estava envolvido, que tinha uma sensibilidade para a questão indígena; eram poucos Bispos, cinco ou dez, não mais do que isso, depois aumentou esse número. Foi muito difícil para o CIMI ter o apoio das missões tradicionais da Igreja Católica. A gente nunca pode esquecer que o grande trabalho com índio no Brasil sempre foi conduzido pelas grandes missões religiosas, especialmente por padres jesuítas, padres salesianos, padres franciscanos, os padres da Consolata em Roraima, Salesianos aqui no Mato Grosso e Amazonas. Então, o trabalho da Igreja Católica com os índios sempre foi histórico, desde as grandes missões. O CIMI, quando fez esse levantamento em mil e novecentos..., no início da década de 1970, no início de sua fundação, levantou a situação dos índios no Brasil inteiro. A grande parte dos povos não tinha nenhuma presença da Igreja, os Bispos ignoravam 
os índios e o CIMI, ele se estrutura um pouco nesse sentido, à margem dessas Missões. Eu diria totalmente à margem, embora o primeiro presidente tenha sido um padre Salesiano, e o segundo presidente tenha sido também um missionário do Instituto Antropos, o Pe. Vicente Cézar. O CIMI, para se estruturar, se apoiou mais no trabalho leigo, concretamente nos voluntários da Operação Anchieta. Então, dentro da Instituição da Igreja Institucional, ele tem apoio de alguns Bispos, basicamente Dom Pedro, Dom Tomaz e de alguns outros, e com fortíssimo apoio da Missão Anchieta dos padres Jesuítas, porque os padres Jesuítas, por diversas razões que não cabe aqui citar, no bojo de Barbados e muitos outros encontros, fazem uma mudança radical na Missão Anchieta, em 1969, para 1970 e 1971, eles fecham os internatos, os padres vão viver nas aldeias. Há uma mudança radical na Missão dos padres Jesuítas, Missão Anchieta em Mato Grosso [MT]. O CIMI, desde antes, no seu início, vai estar apoiado em alguns... sim, em um grupo de missionários religiosos, basicamente Jesuítas e alguns outros Salesianos também, mas só os padres mais... eu diria... da periferia das suas congregações e um grupo de leigos fortemente apoiados na OPAN. Então tem muitos... porque na Igreja tinha muitos conflitos, porque o CIMI começou a bater de frente com o governo, e muitos discordavam disso, achavam que o trabalho da Igreja e do CIMI devia ser a evangelização, e que o CIMI não devia se envolver na questão da terra. Enfim, teve a morte de missionários, e tudo isso acirrou muito as contradições dentro da Igreja. A mesma coisa aconteceu aqui no MS; muitos Bispos discordavam abertamente do posicionamento do CIMI no que se refere ao envolvimento na questão da terra, eles achavam que a Igreja devia se centrar na questão da evangelização e, portanto, não era admitido ao CIMI conflitar com o Estado. E esta questão foi crescendo nacionalmente, essa oposição, esse conflito. Então, acabou surgindo na CNBB, digamos assim, uma tendência de tomar o CIMI como órgão oficial, anexar o CIMI à CNBB era entendido pelos Bispos que queriam isso como uma forma de controlar o CIMI. A anexação, ela foi, na opinião de boa parte do episcopado, uma forma de enquadrar o CIMI nas normas da CNBB, porque eles diziam que o CIMI tinha muita autonomia e que essa autonomia... porque era um órgão anexo, enfim não era um órgão só relacionado, então falava em nome da Igreja no Brasil; de toda maneira falava, mas... nesse sentido, com esse objetivo, eles achavam que anexando a ele, tornando um órgão anexo, eles conseguiriam enquadrar o CIMI nas normas da Igreja, conter esse ímpeto do CIMI de se engajar na questão da terra, de agredir o governo; enfim, dos conflitos. No entanto o resultado não tem sido esse, eu diria hoje que isso não tem interferido negativamente nos posicionamentos do CIMI. Eu creio que a linha de trabalho do CIMI não foi sensivelmente comprometida com esta anexação, embora tenha sido esse o objetivo de muitos, eu não o vejo. Eu creio que os conflitos, eles persistem até hoje, a Igreja sempre tem muitas posições divergentes frente a isso, é óbvio 
em uma instituição dessa! Mas não creio que se possa dizer hoje, olhando pra trás, que o fato do CIMI ter sido anexado a um órgão, transformado em órgão oficial da CNBB, tenha interferido visivelmente ou significativamente na sua linha de trabalho.

\section{A carta assinada pelos Bispos enviada a CNBB com críticas ao CIMI é an- terior à anexação do CIMI a CNBB?}

BRAND: É anterior. Esta carta inclusive, se eu estou bem lembrado, ela que provoca e gera essa discussão da anexação, é a carta dos Bispos do MT. Essa carta ela foi escrita num encontro da reunião dos Bispos de Mato Grosso e Mato Grosso do Norte que formavam o mesmo regional da CNBB. Reuniram então todos os Bispos, dos dois MT. Foi dentro desse contexto que Dom Teodardo assinou a carta também, ele falou isso para nós. E nesse sentido, realmente eu acho que a Igreja sempre foi bastante fechada no que se refere à questão da pastoral da teologia. Dom Teodardo, que foi um Bispo que sempre apoiou muito a luta dos Guarani no que se refere a terra, na questão dos direitos, porque ele entendia como uma luta pelos direitos humanos, teologicamente ele sempre estava convencido de que nós tínhamos que fazer catequese, tínhamos que anunciar o evangelho e muitos Bispos do MT e MS não concordaram. Mas também tinham uns que tinham essa visão fechada que se refere à pastoral e também não concordavam com essa postura, que se refere à terra. Então essa carta pra mim, é uma carta perfeitamente compreensível naquele contexto em que estava forte o conflito do CIMI com a Igreja. Isso pra mim, nacionalmente, porque na Assembleia Nacional de Pastoral Indigenista, em que decisões foram tomadas por diferença de um ou dois votos, era muito conflitivo. Mas o Dom Teodardo, já entrando nessa questão da relação com os Bispos, foi uma pessoa que tinha uma grande sensibilidade com essa questão dos direitos humanos, na hora que ele enxergava, que conseguia visualizar que estava em jogo os direitos humanos de uma população, ele não tinha nenhum medo de confrontar com o governo, sempre nos apoiou decididamente neste ponto. Então isso é um dado, é uma questão que tem que ser reconhecida, e todas as denúncias que nós fizemos nesse período todo, denunciando as agressões dos direitos indígenas, sempre contamos com o apoio explícito e direto dele, o que não quer dizer aquilo que eu já falei, que no campo da pastoral da teologia ele não estivesse convencido de que nós já devíamos estar começando a catequese. 


\section{Como foi o trabalho do CIMI em relação à retomada das terras Guarani/ Kaiowá?}

BRAND: Como eu falei, nós quando fomos, eu no caso, quando eu fui para Dourados, eu vinha no bojo de toda essa discussão da terra indígena no Brasil, em 1995. Em 1975, eu fui fazer um grande levantamento no Maranhão sobre a questão das terras indígenas do Maranhão, e em muitos outros lugares, e nós também vínhamos com as informações que estavam em alguns relatórios prévios do CIMI, dando conta dessa situação de confinamento dos índios, uma situação extremamente precária no que se refere à terra. Então, ao chegar em MT, em Dourados... bom, a minha ida a Dourados também se dá no bojo de um outro fato que me marcou muito. Eu cheguei a Dourados dia 12 de setembro de 1978 e, dia 15, o meu primeiro contato com os Guarani foi exatamente para fazer o levantamento de uma aldeia inteira que tinha sido expulsa, e trazidos para Bodoquena, que eram os índios do Rancho Jacaré. Fui fazer o levantamento de dezoito casas queimadas, foi o meu primeiro trabalho com os Guarani. Eu fui junto com outros colegas, e o que eu vi, o meu primeiro impacto, foi uma aldeia inteira sendo transferida em caminhões de gado, forçado, numa operação de cooperação entre a FUNAI e a Companhia Matte Laranjeira. Jogaram os índios em Bodoquena e, ao mesmo tempo, eu li nos jornais da época, o administrador regional da FUNAI (que até hoje, aliás, está aqui) dizendo que se previa um êxodo de índios para Bodoquena. Mas antes disso, também, dois meses antes de vir pra cá, eu tinha lido outra matéria em que a FUNAI também tinha desalojado violentamente os índios, um grupo de índios Ofaié-Xavante de Brasilândia, e levado para Bodoquena. O primeiro ato político meu aqui foi fazer esse levantamento e fazer uma nota, que a Diocese publicou, denunciando essa destruição da aldeia do Rancho Jacaré. Então nós chegamos aqui com bastante clareza sobre essa questão de fundo, que era a questão da terra, e o Rancho Jacaré entrou diretamente por causa disso. Depois - esse fato é conhecido -, os índios foram levados para Bodoquena, o presidente da FUNAI, com a denúncia da Diocese, e também de um grupo de antropólogos, que denunciou isso em Campinas, foi obrigado a reconhecer que essa transferência foi ilegal (em 1978, já tínhamos todas as legislações). Aí falou que os índios iam ser trazidos de volta. O presidente da FUNAI fez uma nota, no entanto os índios estavam em Bodoquena, a FUNAI não queria transportar de volta, e um dia eles resolveram pôr-se na estrada a pé, e a FUNAI os trouxe para a aldeia de Dourados. Pediu para eles ficarem lá por duas ou três semanas, o tempo necessário, segundo a FUNAI, para regularizar a entrada, a volta oficial deles na aldeia. A FUNAI os alojou no posto, ficaram lá durante duas ou três semanas; foram passando meses, deu uma epidemia de varíola, morreram muitas crianças. E um dia os índios vieram pedir para nós (a gente visitava eles muito) se a gente apoiava a eles 
com comida, se eles entrassem por conta dentro da fazenda de novo, isso um ano depois. De novo fomos falar com o Bispo Dom Teodardo: “-Antonio, isso é uma questão de direitos humanos, nós vamos dar comida sim". Então eles entraram de fato, eles voltaram na noite, entraram por conta.

\section{Eles voltaram a pé de Bodoquena?}

BRAND: Não, Bodoquena ${ }^{1}$, eles vieram pela estrada, a FUNAI depois os trouxe até Dourados, alojou eles no antigo posto da FUNAI, em Dourados, que hoje não existe mais. Lá então disseram que iam ficar três semanas, na verdade ficaram meses, deu uma epidemia de varíola, morreu muita gente e daí eles resolveram voltar de Dourados, a pé, para entrar no Rancho Jacaré. Para isso eles vieram pedir o apoio nosso, da Diocese, do CIMI. Então nos comprometemos em oferecer comida, sementes, ferramentas, essas coisas, porque havia passado um ano e o gado tinha sido solto na terra deles, então não tinha nada mais lá e eles entraram. E, de fato, durante uns três ou quatro meses, isso eu e o resto da equipe, às vezes a gente alternava, todo sábado nós levávamos uma carga de comida em alguma cerca próxima ao Rancho Jacaré, porque a Fazenda fechou todas as entradas. E a FUNAI, junto com a fazenda, tentando remover os índios. Depois desse tempo, a FUNAI, eu diria, criou vergonha e interveio, e a área começou realmente a ser reconhecida como Área Indígena. Bom, o nosso envolvimento mais direto com o Rancho Jacaré naquele tempo, foi o primeiro caso; no meio disso também nós começamos a ir junto com os antropólogos do PKN [Projeto Kaiowá-Ñandeva] tomar contato com a Paraguassu. É uma outra área lá em Paranhos, na qual os índios também tinham sido expulsos de uma parte da área, no ano anterior, e estavam numa tensão grande, sendo expulsos várias vezes. E a gente começou a se envolver também com esta questão da Paraguassu, no sentido de apoiar a permanência deles etc. e tal. O nosso trabalho, na época, no que se refere à demarcação... e o próximo caso foi Pirakuá. O Pirakuá é um caso que... bom, cabe dizer que nesse tempo trabalhava diretamente conosco o Marçal $^{2}$, era um grande companheiro de viagem, trabalhava muito ligado a nós, ele sempre foi, eu diria totalmente identificado com o CIMI, desde que nós começamos lá, e então o Marçal, ele trabalhava de enfermeiro na Aldeia

\footnotetext{
${ }^{1}$ Do município de Bodoquena a Dourados há aproximadamente $330 \mathrm{~km}$.

${ }^{2}$ Marçal de Souza ou Marçal Tupã'i, foi uma das primeiras lideranças guarani a denunciar publicamente o esbulho territorial, a exploração ilegal de madeira e a escravização de índios que ocorria no MS. Ele foi covardemente assassinado em 1983. Os acusados do crime, o fazendeiro Líbero Monteiro de Lima e seu capataz, Rômulo Gamarra, foram absolvidos do homicídio. A morte de Marçal afetou profundamente Antonio Brand, que o tinha como um companheiro de luta e um amigo.
} 
de Campestre, enfermeiro da FUNAI. E ele, muitas vezes, me havia falado de um grupo de índios que tinha na cabeceira do Rio Apa. Em julho de 1980, eu e outro padre da Diocese estávamos em Campestre e fomos com ele procurar esses índios, encontramos com os índios lá na beira do Rio Apa, e foi feito o mesmo processo que realizamos em outros casos. Então, o que a gente fazia nesses casos, duas atitudes sempre foram, digamos assim, as primeiras atitudes que a gente, pelo CIMI, tomava e implementava: uma primeira era fazer tudo para que os índios pudessem ficar, e não sair. Pirakuá, em junho, estava tudo acertado com os fazendeiros que os índios sairiam em outubro daquele ano, abandonariam a fazenda, isso já estava negociado com o fazendeiro e com os índios, porque eles achavam que não tinham direito. A FUNAI sempre dizia que lugar de índio era nas reservas demarcadas pelo SPI. E, automaticamente, a FUNAI era a primeira a dizer para os índios que eles não tinham direitos na terra. É importante que se diga isso, a FUNAI era a primeira a cooperar com os fazendeiros para retirar os índios das terras. No Pirakuá, os índios já tinham negociado pequenos lotes na cidade de Antônio João; em outubro eles sairiam da terra, quando o desmatamento deveria estar mais ou menos concluído, iriam ocupar o resto das áreas. Na Paraguassu foi idêntico, a primeira questão era como mantê-los lá. Em quase todos os casos, nós entravamos com projetos agrícolas, fornecendo sementes, fornecendo ferramentas e dando apoio para eles cultivarem a terra e não dependerem mais do assalariamento, da derrubada dos fazendeiros, e também no Pirakuá fizemos isso. Imediatamente fazíamos novamente relatórios provisórios. Ainda achei outro dia os relatórios com croqui. Apoiávamos a ida dos índios para a FUNAI em Brasília, a mesma coisa foi feita na Paraguassu e no Rancho Jacaré. O CIMI pagava as despesas todas, mobilizava a ida deles para pressionar diretamente a FUNAI, para começar a tramitação do processo de identificação da área. Então normalmente nós fazíamos um relatório com croqui, com número de famílias, um pequeno histórico, e eles iam a Brasília, pela lei eles tinham direito já naquele tempo. A FUNAI, muitas vezes não tinha como oficialmente dizer que os índios tinham direito e diziam que iam encaminhar; obviamente que nada disso acontecia. O trabalho do CIMI na questão da terra foi muito; desde o início foi neste sentido de apoiar a permanência, e a forma de apoio eram basicamente projetos, apoio agrícola, apoio político, visita, denúncias por conta do alto índice de violência. Em todas as negociações da FUNAI, o CIMI tinha uma equipe muito forte em Brasília e acompanhava tudo, a gente sabia como a FUNAI estava articulando as negociações em curso. Tem um dado aqui que eu acho que é muito importante destacar, o CIMI era o único órgão não oficial que tinha uma articulação nacional. O CIMI estava em todos os estados, praticamente, e tinha uma sede em Brasília extremamente bem organizada. A gente sabia, o pessoal acompanhava, em Brasília, reuniões com o Presidente da FUNAI, a gente sempre tinha as informações, muitas vezes 
nós conseguíamos denunciar antes que os atos acontecessem. Isso fortalecia muito a luta dos índios; eu acho que era um aspecto fundamental pra nós, a denúncia naquele tempo, 1978 até 1983, 1982, era o recurso fundamental, porque era a forma de você (na nossa maneira de ver, estou convencido disso até hoje) fortalecer. O maior e melhor apoio que nós podíamos dar aos índios não era tanto a ajuda direta, mas era o apoio político da Igreja, e nós tínhamos consciência disso. Então, muitas denúncias a Igreja podia fazer, só a Igreja, porque nenhum antropólogo sozinho teria condições políticas de fazer isso, porque a Igreja com toda aquela estrutura, mesmo com suas contradições, nos dava uma tranquilidade, e isso eu acho que nós utilizamos muito, a nossa vinculação à Igreja, a nossa pertença, fazia com que tivéssemos credibilidade para denunciarmos. Você vai ver em todos os relatos que você for olhar do CIMI, muitas denúncias, mas era também junto com o apoio concreto no campo da produção e outras coisas mais.

\section{Em relação ao campo da produção, as roças comunitárias, elas foram uma forma de conseguir a confiança dos índios pra discutir a questão da terra?}

BRAND: Olha, fundamentalmente, as roças comunitárias de fato não era um objetivo, era uma questão muito complexa. A gente também entendia que a dependência da changa ${ }^{3}$ era uma coisa ruim, então sempre tinha como meta, eu diria hoje equivocadamente, acho que houve equívocos na leitura nobre de que isso era um grande problema, hoje acho que não era. Mas a gente tinha como meta sempre a autonomia. Havia toda uma outra discussão que o CIMI levou muito, foi a questão da autodeterminação dos povos indígenas. O que era necessário para a autodeterminação dos povos indígenas? Primeiro, o território; segundo, tinha que ter certa autonomia interna no campo da produção, então as roças entraram muito nesse bojo. De um lado, era uma forma de você estar lá e ter uma relação, era uma coisa que eles queriam muito, buscavam muito apoio e era também na perspectiva da luta. A outra parte, que era quebrar essa dependência, que a gente entendia na época como dependência da

\footnotetext{
${ }^{3}$ Entendida pelos índios como "trabalho" para os de fora, a changa é uma atividade antiga, já que a força de trabalho Guarani tem sido utilizada no decorrer dos últimos 500 anos na implementação de variadas iniciativas econômicas. Trata- se de uma atividade temporária, sem vínculo e, de um modo geral, sob condições desfavoráveis. Regionalmente, é considerado um "trabalho de Bugre", termo utilizado para se referir aos Kaiowa e Nandeva quando trabalham em fazendas. Almeida afirma que para se entender esse processo da changa é necessário ter em mente o universo das relações históricas Guarani e suas variadas relações econômicas com agentes externos ao longo dos anos. Essa modalidade de trabalho propicia um processo de conhecimento do jovem com o mundo "civilizado", e o seu acesso ao dinheiro, consequentemente, a bens considerados necessários e que, certamente, ele não conseguiria apenas com o trabalho interno na aldeia (Almeida, R.T. Do desenvolvimento comunitário à mobilização política - O projeto Kaiowá-Ñandeva como experiência antropológica. Rio de Janeiro: Contra Capa, 2001, p. 159).
} 
changa, hoje - como eu falei - , acho que é uma questão menos importante esse trabalho na changa. Enfim, não era esse o grande problema, mas na época nós investimos muito nisso. As roças comunitárias tinham um pouco essa dupla, essa tripla função, era uma forma de você estar lá e logicamente discutindo essa questão mais ampla da terra; mas era também uma forma de você apoiar uma maior autonomia dos índios frente ao trabalho nas changas, e era também uma forma de você... mostrar, viabilizar a necessidade da própria terra nesse sentido de cultivar. Foi importante esse trabalho das roças, acho que foi uma cooperação importante com o PKN, que na verdade o Rubem Thomaz de Almeida já vinha desenvolvendo um trabalho semelhante lá. E eu creio que conseguimos, ainda no bojo das roças, discutir muitas outras questões. Isso é um aspecto importante e, acima de tudo, foi no âmbito das roças que começamos (eu creio que em 1978) o encontro sistemático de cabeçantes de grupos de roças, que logo mais se transformaram em encontros de lideranças indígenas Kaiowá Guarani e em Aty Guasu. As origens do encontro da Aty Guasu, ele surge no bojo dos encontros dos cabeçantes de roças, que eram feitos conjuntamente entre o PKN e CIMI, com a colaboração de alguns funcionários da FUNAI. Tinha alguns dos funcionários, chefes de posto da FUNAI, que tinham clareza... porque, quando a gente fala da FUNAI, fala do órgão em sua política global, o que não quer dizer que não havia funcionários excelentes, de uma compreensão muito boa da situação indígena e que apoiavam muitíssimo o nosso trabalho, e isso é importante dizer quando a gente fala, a FUNAI é o órgão que, na sua política global, ele tinha realmente uma postura que era terrível. Esse projeto nosso, eu creio que ele era muito importante, - eu diria não tanto pela produção das roças, embora olhando, ainda acho que foi um período de muita produção -, mas pelo o que ele permitiu gerar, e basicamente quebrou o isolamento das aldeias naquela época. Isso é muito importante; o índio para sair de uma aldeia, visitar parentes em outra aldeia, tinha que ter licença da FUNAI, senão ele era preso. Havia um controle, uma rigidez, um fechamento, um domínio da FUNAI muito forte e esse foi, eu diria, o espaço mais importante para quebrar esse domínio da FUNAI, foram essas reuniões, primeiro de cabeçantes, depois incorporando capitães, incorporando caciques, esse processo foi depois crescendo e ampliando.

\section{Como foi a participação do CIMI na Aty Guasu?}

BRAND: Na época essas reuniões eram sempre discutidas conjuntamente, no caso, acho que posso dizer com fidelidade que era uma iniciativa conjunta PKN e CIMI, fundamentalmente. E a gente dividia transporte, enfim, isso era uma cooperação, mesmo porque, para sair esta reunião, a gente tinha que garantir transporte, garantir comida. Muitas vezes, tinha problemas políticos; a FUNAI 
não permitia realizar em uma área ou em outra área, então a gente participava disso também, mas acima de tudo, a gente oferecia junto com o PKN (sempre foi um trabalho conjunto) a estrutura necessária e política. Uma coisa é esse trabalho político para que esses encontros pudessem acontecer e, junto com esses encontros, também era desenvolvido o projeto de roças, que tinha nas aldeias demarcadas, nas reservas, e tinha também um trabalho nas áreas de conflitos. Então, desde o início, em meio às roças, era discutida a questão da terra de fato, porque o pessoal do Rancho Jacaré ia às reuniões, o pessoal da Paraguassu ia nessas reuniões e o pessoal do Pirakuá. Desde o início, esses encontros, que eu acho que foi o fator mais importante do trabalho, e aí eu não digo... o trabalho do CIMI e do PKN; eu diria, esse é um trabalho conjunto. O objetivo inicial era o encontro de cabeçantes, para que eles pudessem trocar experiências, a questão da produção, mas como ele incluía as áreas de conflito desde o início, isso foi o fórum mais importante talvez para o desdobramento posterior da luta dos Guarani. E daí, eu diria assim, a sacação mais importante foi essa de fazer a cada três ou quatro meses (reuniões); eram sistemáticas.

\section{Como foi seu trabalho com o CIMI e os Guarani/Kaiowá em relação à terra quando você estava no Secretariado Nacional?}

BRAND: Tinha uma outra equipe aqui no regional, então eles continuaram certamente tocando, eu fiquei no apoio mais indireto; os Guarani vieram inúmeras vezes a Brasília atrás das questões da terra, eu vim algumas vezes aqui, mas era um apoio mais indireto. O período em que estive no secretariado, naturalmente aumentou muito o trabalho com outras regiões e outras questões. Mas, eu não me lembro agora quantas vezes; eu vim inúmeras vezes para cá, e os Guarani foram muitas vezes à Brasília atrás de questões da terra, muitas vezes. Mas era um apoio mais indireto, não tão presente, aqui eu realmente não consegui permanecer. E um dado que é importante é que a minha eleição para secretariado do CIMI, isso em 1983, isso foi três meses antes da morte do Marçal. O assassinato do Marçal foi um fato que abalou muitíssimo muita gente, a mim também. Marçal era muito amigo, ele trabalhava muito junto, especialmente no Pirakuá. Ele fez inúmeras e inúmeras viagens e peripécias, que vivemos juntos lá.

\section{Qual o período que você ficou no Secretariado Nacional?}

BRAND: De 1983 a 1991. Então vou falar da questão do PKN e com a FUNAI. Com o PKN nós tínhamos no início, eu diria, bastante divergências. Eu acho que fomos superando muito as divergências, discutimos muito. Eu acho que foi um período de uma cooperação muito positiva e de muita aprendizagem 
para mim, - não sou antropólogo - , enfim, muita aprendizagem e achei que foi... lamento profundamente que hoje isso não seja mais possível, esse número de discussão que a gente tinha na época, mesmo com as divergências. Mas no fundamental nós sempre nos apoiamos um ao outro, politicamente e também perante aos índios, nas discussões, e isso era coisa que - eu volto a dizer - acho que se perdeu muito, isso é uma grande perda para os índios, com todas as divergências que tivemos. Eu considero que o trabalho, o PKN sozinho não teria conseguido fazer e nós sozinhos tampouco. Então, essa questão da cooperação que - eu volto a dizer - não foi tranquilo, tinha muitos conflitos, momentos de tensão, divergências, mas tudo isso faz parte, no fundamental nós nos encontrávamos. Com os índios, eu diria, a relação sempre foi a melhor possível. Com os índios, às vezes, tinha problemas, porque a FUNAI também jogava alguns índios contra nós, enfim, manipulava algumas lideranças. Então, às vezes, tinha uns índios que falavam contra o trabalho da Igreja, do CIMI, mas nunca algo mais significativo e, eu diria que, sempre - pelo menos no período que eu estive aqui - eu tive uma excelente relação com os Guarani e nunca percebi, ao contrário, senti uma grande aceitação do trabalho. Agora, nós nunca nos engajamos em trabalhos de catequese, nós nunca nos engajamos em trabalhos de, digamos assim, evangelização.

\section{Após a sua formação acadêmica e após a sua volta para Mato Grosso do Sul você continuou com alguma atividade no CIMI?}

BRAND: Não, quando eu vim pra cá eu vim já com outra proposta, de vincular à Universidade. Lógico, minha expectativa era também de continuar contribuindo com o CIMI, porque afinal foi um trabalho que eu me considero em grande parte responsável pela sua estruturação aqui no estado, e fui eu, talvez, uns dos poucos membros do CIMI a participar de todas as Assembleias do CIMI nos primeiros vinte e cinco anos do órgão. Então minha participação, minha relação com o CIMI era muito intensa. Mas eu vim aqui já na decisão prévia de me engajar prioritariamente na Universidade por questões, eu diria, conjunturais da equipe local, que estava nesse momento aqui no CIMI. Isso não se verificou; de fato não foi possível uma cooperação mais sistemática. O projeto que eu vinha alimentando, ao vir para cá, era o seguinte: o que eu tinha percebido durante o doutorado, o mestrado e participando de encontros diversos fora do CIMI, nas Universidades, é muito difícil uma Universidade desenvolver: um trabalho em Área Indígena e garantindo uma continuidade, uma resposta efetiva ao que os índios buscam. Na verdade, esse trabalho das Universidades era o que eu via, que eu tinha conhecido, eram trabalhos pontuais, muito mais voltados para o pesquisador ou para a Universidade que para a comunidade. Isso para mim era uma coisa muito complicada. Ao mesmo tempo, eu achava, pelo que eu tinha já percebido, que a Universidade 
podia prestar um serviço importante. Então, a ideia que eu trazia era de uma cooperação da Universidade com o CIMI. Isso era realmente o que eu pensei que seria possível ao vir pra cá, estando na Universidade, montando equipes de pesquisas, trabalhando na Universidade, mas em parceria com o CIMI e outros organismos que pudessem ter uma cooperação, onde a Universidade entraria com aquilo que ela pode e que uma ONG tem dificuldade. E haveria então essa complementação; isso iniciaria se as ações das Universidades não fossem fragmentadas, interrompidas. Mas eu não consegui fazer com o CIMI, e conseguimos estruturar isso com a Diocese de Dourados fora do CIMI. E é disso que vem hoje, que é mais conhecido, o Programa Kaiowá/Guarani. Ele vem dessa visão não só minha, mas de outros colegas também, de que hoje, especialmente na realidade de MS, é muito difícil você justificar a presença de um pesquisador na área, pesquisador tradicional, que faz sua pesquisa e depois vai embora. E que efetivamente os povos indígenas cobram isso, é direito deles o retorno desse trabalho e a forma de dar retorno para que ele tenha consistência. Eu estou hoje convencido de que só é possível mediante cooperação, organização, cooperação. Cooperação com quem? Órgãos do governo? pode ser, ou ONGS, ou outras instâncias, enfim, mas tem que ser em forma de cooperação.

Recebido em 02 de agosto de 2012

Aprovado para publicação em 23 de agosto de 2012 